\title{
FAILURE TO TRANSMIT MUTANT PLASTIDS IN A PELARGONIUM CROSS
}

\author{
R. A. E. TILNEY-BASSETT \\ Botany School, Oxford
}

Received 27.ii.64

\section{INTRODUCTION}

Reciprocal crosses between Pelargonium zonale cultivars with green germ layers and cultivars with white germ layers produce green, variegated and white offspring in proportions related to the individual plastid contributions of the two parents. Intercultivar crosses involving five different white-overgreen chimeras with white germ layers agreed with this principle, but a sixth W-o-G chimera, Kathleen Harrop, when crossed with the wholly green cultivar Paul Crampel, gave only green offspring (table IA). I suggested

\section{TABLE IA}

Results of selfing and reciprocal crosses between the Pelargonium chimera, Kathleen Harrop, with a white germ layer and the wholly green variety, Paul Crampel

\begin{tabular}{|c|c|c|c|c|c|c|c|c|c|}
\hline \multirow{3}{*}{$\begin{array}{l}\text { Self or } \\
\text { cross }\end{array}$} & \multicolumn{6}{|c|}{ Total Nos. and percentages } & & & \\
\hline & \multirow{2}{*}{$\begin{array}{l}\text { Ovules } \\
\text { pollnd. }\end{array}$} & \multicolumn{4}{|c|}{ Seeds } & \multirow{2}{*}{$\begin{array}{l}\text { T. fertility } \\
\text { (per cent.) }\end{array}$} & \multicolumn{3}{|c|}{ Offspring } \\
\hline & & Full & $\begin{array}{c}\text { Full } \\
\text { (per cent.) }\end{array}$ & Germd. & $\begin{array}{c}\text { Germd. } \\
\text { (per cent.) }\end{array}$ & & G & V & W \\
\hline $\begin{array}{l}G \text { self } \\
G \times W \\
W \times G \\
W \text { self }\end{array}$ & $\begin{array}{l}490 \\
* \\
520 \\
*\end{array}$ & $\frac{116}{70}$ & $\frac{23 \cdot 6}{13.5}$ & $\frac{97}{63}$ & $\frac{83 \cdot 6}{90 \cdot 0}$ & $\frac{19.8}{12 \cdot 1}$ & $\begin{array}{r}97 \\
3 \\
63 \\
\end{array}$ & $\frac{-}{-}$ & - \\
\hline
\end{tabular}

* K. Harrop is male sterile; it has only once produced good pollen which was used in the cross with Paul Crampel.

$\left(\mathrm{r}^{6}{ }^{3} a\right.$ and $\left.\mathrm{I}_{96}{ }^{6} b\right)$ that this would be the expected result if $\mathrm{K}$. Harrop is not a plastid- but a gene-differential chimera. The green seedlings would therefore be the $F_{1}$ heterozygotes of a cross between a homozygous dominant with green phenotype, and a homozygous recessive with white phenotype.

\section{TESTING THE HYPOTHESIS}

To test the hypothesis that $\mathrm{K}$. Harrop is a gene-differential chimera, I potted-up eighteen of the green $F_{1}$ seedlings and flowered all but one in the following summer, 1963. Eight of these were hermaphrodite and nine male sterile. I selfed the hermaphrodites and crossed the females with pollen from the hermaphrodites. The seeds were sown in J.I. Seed Compost as soon as they were ripe, placed in a frame at $25^{\circ} \mathrm{C}$. and kept well watered. All the germinating seeds were green (table IB). 
TABLE IB

Results of selfing and intercrossing the green $F_{1}$ seedlings obtained from crossing Kathleen Harrop and Paul Crampel (table IA)

\begin{tabular}{|c|c|c|c|c|c|c|c|c|c|}
\hline \multirow{3}{*}{$\begin{array}{l}\text { Self or } \\
\text { cross }\end{array}$} & \multicolumn{6}{|c|}{ Total Nos. and percentages } & & & \\
\hline & \multirow{2}{*}{$\begin{array}{l}\text { Ovules } \\
\text { pollnd. }\end{array}$} & \multicolumn{4}{|c|}{ Seeds } & \multirow{2}{*}{$\begin{array}{l}\text { T. fertility } \\
\text { (per cent.) }\end{array}$} & \multicolumn{3}{|c|}{ Offspring } \\
\hline & & Full & $\begin{array}{c}\text { Full } \\
\text { (per cent.) }\end{array}$ & Germd. & $\begin{array}{l}\text { Germd. } \\
\text { (per cent.) }\end{array}$ & & G & $\mathrm{V}$ & W \\
\hline 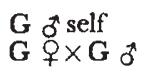 & $\begin{array}{l}1870 \\
1400\end{array}$ & $\begin{array}{l}278 \\
266\end{array}$ & $\begin{array}{l}14 \cdot 9 \\
19 \cdot 0\end{array}$ & $\begin{array}{l}243 \\
245\end{array}$ & $\begin{array}{l}87 \cdot 4 \\
92 \cdot 1\end{array}$ & $\begin{array}{l}13.0 \\
17.5\end{array}$ & $\begin{array}{l}243 \\
245\end{array}$ & - & 二 \\
\hline Totals & 3270 & 544 & I6.6 & 488 & $89 \cdot 7$ & 14.9 & 488 & - & - \\
\hline
\end{tabular}

\section{FAILURE TO TRANSMIT MUTANT WHITE PLASTIDS}

The $\mathrm{F}_{2}$ offspring showed no Mendelian segregation into green and white seedlings but were entirely green (table IB). Moreover, the total fertility for the $F_{2}$ generation is slightly higher than for the $F_{1}$ so there is no reason to argue that the absence of the expected segregation is due to the inviability of numerous potentially white seedlings. My hypothesis that K. Harrop is a gene-differential chimera is therefore no longer tenable. The vegetative parts of two confirmed plastid-differential chimeras with white germ layers, Flower of Spring and J. C. Mapping, are indistinguishable from K. Harrop. The only apparent justification for separating the three as distinct cultivars is that they differ in flower colour and size and in the male sterility of $\mathrm{K}$. Harrop. I believe that these two kinds of observation constitute reasonable grounds for considering that K. Harrop is, after all, a plastid-differential chimera similar to the five other Pelargonium chimeras, including Flower of Spring and J. C. Mapping, with which I made breeding experiments ( $1963 b)$.

When F. of Spring was crossed with P. Crampel about one-third of the offspring were variegated or white showing that white plastids had been successfully transmitted. Whereas, within the limits of the number of seedlings produced by the crosses, the mutant white plastids from $\mathrm{K}$. Harrop completely failed to be transmitted. This resulted in the exceptional, purely paternal inheritance of green plastids in the $\mathrm{W} \times \mathrm{G}$ cross as opposed to the maternal inheritance of the same green plastids in the reciprocal, $\mathrm{G} \times \mathrm{W}$ cross. The behaviour of the two kinds of plastid is evidently more important than the direction of the cross. I do not know exactly what happens to the white plastids but I suggest that one or other or both of the following reasons could explain their failure to be transmitted:

I. Far fewer white than green plastids are contributed to the fertilised egg so that during subsequent embryo development the white plastids are completely swamped by the green.

2. The green plastids multiply more rapidly than the white. This would be particularly important in the zygote and in the first few divisions of the embryo when the two kinds of plastid are together in the same, mixed cell. 
Under these circumstances, with each successive cell division there could be so rapid an increase of green plastids over white that the white plastids would be overwhelmed without ever having sorted-out to give any pure white cells. Similarly, mixed cells would rapidly be outnumbered by pure green cells.

No doubt other explanations can also be given but we need to know much more about these little studied mutant plastids before we can draw any firm conclusions relating to such peculiarities of plastid transmission.

Acknowledgments.-I wish to thank Professor C. D. Darlington, F.R.S., for his advice and encouragement throughout the course of this work which has been made possible by a D.S.I.R. research grant.

\section{REFERENCES}

TILNEY-BASSETT, R. A. E. I963a. The structure of periclinal chimeras. Heredity, I8, $265-285$.

TILNEY-BASSETT, R. A. E. I963b. Genetics and plastid physiology in Pelargonium. Heredity, $18,485-504$. 